\title{
Microbiological Study of Costal Shrimp Aquaculture Production System of Bangladesh
}

\author{
Md. Reazul Karim (Corresponding Author), \\ Md. Naqib Uddin, Md. Khalilur Rahman \& Md. Akim Uddin \\ Department of Microbiology, University of Chittagong, Chittagong-4331, Bangladesh. \\ E-mail: reazul.m.karim@gmail.com
}

Received: November 27, 2017

Accepted: December 14, 2017

doi:10.5296/jbls.v9i1.12195

URL: https://doi.org/10.5296/jbls.v9i1.12195

\begin{abstract}
The study was intended to identify the common pathogen from water and soil sample of some costal shrimp Hatchery and Fisheries of Bangladesh and to demonstrate the probiotic efficacy against this pathogen. 8 samples were taken from 6 individual costal shrimp Hatchery and bacterial load was determined from them. During the period of study, a total number of 20 bacterial colonies were isolated according to morphological characteristics. Among them, 7 groups of isolates were screened for detail study, based on of their morphological and cultural characteristics. The isolates were identified through biochemical and microbiological characteristics as Aeromonas salmonicida, Vibrio parahaemolyticus, Bacillus fastidiosus, Vibrio vulnificus, E. coli, Vibrio harveyi and Aeromonas bestiarum. The susceptibility of the selected isolates against traditional antibiotic was performed by agar diffusion method using antibiotic disc. Rifampicin showed inhibitory effect against almost all organisms where as ampicillin is the antibiotic which had no effect on either of the isolates and penicillin is less effective than other antibiotics used. Probiotic efficacy of Bacillus \& Pediococcus against the selected isolates was performed. Bacillus and Pediococcus showed a satisfactory antimicrobial effect against the selected isolates which revealed that; they are favorable for the biocontrol of microbial flora in shrimp hatchery and aquaculture.
\end{abstract}

Keywords: Costal shrimp Hatchery, Fisheries, Pathogen, Probiotics, Biocontrol

\section{Introduction}

Aquaculture remains a growing, vibrant and important production sector for high protein animal food that $s$ easily digestible and of high biological value. In respect to aquaculture, shrimp culture plays an important role in Bangladesh. One of the major constraints for the development of shrimp aquaculture is the mortality due to diseases (Lin, C.K., 1995 \& 
Subasinghe, R. 1997). Bacterial diseases mainly due to Vibrio have been reported in penaeid shrimp culture system implicating at least14 species and they are $V$. harveyi, V. fishceri, $V$. splendidus, V. vulnificus etc. A number of recent reports, press releases and on-going investigations have raised legitimate public concerns about the safety of antibiotic drug usage in aquaculture (Alderman, D. J, 1998). Vibrio cholerae is one of the important etiological agents in mass mortalities of Penaeus monodon rearing systems. To control microbial diseases, a number of chemotherapeutic agents including antibiotics are used in shrimp farms. This has led to problems such as antibiotic resistance (Karunasagar, I., 1994). According to WHO fact sheet 194 (World Health Organization Antimicrobial Resistance Fact Sheet 194), the massive use of antimicrobials for disease control and growth promotion in animals increases selective pressure on the microbial world and encourages the emergence of resistant bacteria which can transfer their resistance genes to other bacteria. An alternative method of controlling pathogenic bacterial strains in shrimp cultures could be supplementation of pure cultures of natural bacterial isolates (biocontrol) which might produce chemical substances inhibiting the growth of pathogens. The approach basically employs the activity of microorganism that could suppress or inhibit the growth of $V$. harveyi without causing bad impact on the equilibrium system in a particular microbial community. (Ohhira, I.,1996) This practice has recently been observed in aquatic systems such as fish culture and crustacean culture. The present study is an attempt to identify the list of pathogenic bacteria exist in natural environment as well as in hatcheries, surrounding water body (supply water and soil) and culture farm through microbial and biochemical analysis and assess the antibiotic resistance status of the pathogen due to bad practiced by the hatchery and farm. Moreover, trying to find out alternative approach to mitigate this pathogen through probiotic efficacy test.

\section{Material and Method}

\subsection{Sampling Site}

Selected sampling sites/ points were in Cox's Bazar area both for shrimp hatchery and grow-out pond operation.

- For Shrimp Hatchery: Cox's Bazar: Kolatoli, Sonapara

- For Grow-out pond operation: Kurushkul (Beximco Fisheries Ltd.).

\subsection{Sampling Method}

Samples from water and soil were taken at selected sampling sites at regular interval as per activity plan. In addition, feed and live samples at 'different stages of production cycles' at Shrimp Hatchery and Shrimp Grow out pond were taken to check existing 'microbial load' and selected 'water quality' parameters of the respective area following Standard procedures (American Public Health Association (APHA),2002,).

\subsection{Media And Techniques For Enumeration And Isolation of Bacteria}

\subsubsection{Media used}

The following media were used for the enumeration and isolation of colonies of 
microorganism

1. Nutrient agar medium

2. TCBS agar medium

\subsubsection{Techniques Employed}

Three different techniques were applied for the total count and isolation of bacteria: dilution plate, pour plate and spread plate methods (Sanders, E. R. 2012). For the total count and segregation, of discrete bacterial colony serial dilution was carried out up to $10^{6}$. The inoculated media were incubated at $37^{\circ} \mathrm{C}$ for 24 to 48 hours.

\subsection{Enumeration of Bacteria}

After incubation, the plates having well spaced colonies were selected for counting. The selected plates were placed on a colony counter (Stuart Scientific U K) and the colonies were counted. The colonies were calculated by multiplying the average number of colonies per plate by reciprocal of the dilution. The calculated results would be as colony forming units (cfu) per ml of sample.

\subsection{Isolation of Discrete Colonies}

Isolation of well discrete bacterial colonies was done immediately after counting. On the basis of colony morphology, different colonies were selected for isolation. Characters of the colonies were recorded as color, form, elevation, margin, surface etc. Then the marked observed colonies were transferred to nutrient agar slant for further studies.

\subsection{Purification of the Isolates}

The colonies showing unique morphology were purified through consecutive pour plate and streak plate method.. Nutrient agar was used as media. When a plate yielded only one type of colony, the organisms were considered to be pure.

\subsection{Maintenance and Preservation of the selected purified Isolates}

The purified isolates were then transferred to nutrient agar slants. The slants were kept in polythene bags and preserved as stock culture in refrigerator at $4^{0} \mathrm{C}$ for further study. Sub culture of certain interval was maintained to keep the cultures in active condition characters unimpaired.

\subsection{Final Selection of the Isolates}

Final selection was made on the basis of their colony morphology on the agar plate, agar slant and their microscopic features under light microscopy.

\subsection{Coding of the Isolates}

The pure cultures of the isolates were coded according to the number of colonies and the serial of the sample used. The code numbers were maintained and followed till identification of the isolates after through characterization. 


\subsection{Identification of selected Isolates:}

Identification of the microorganisms was a sequential process which included a series of different types of experiments. Selected Isolates. were subjected to biochemical tests and results were compared with standard description given in "Bergey's Manual of Determinative Bacteriology", $8^{\text {th }}$ ed. (Buchanon RE.,1974) and $9^{\text {th }}$ ed. (Holt JG,2000). The tests include Gram-staining, Spore staining Acid-fast staining, starch hydrolysis, Voges Proskauer (V-P) Test, Production of hydrogen sulphide, Gelatin liquefaction test, Nitrate reduction test, Indole test Deep glucose agar test, Catalase reaction Methyl-red test, Fermentation test, Urease test Motility test, Oxidase test Cultural and physiological studies were also done.

\subsection{Antibiotic Susceptibility Test (Bauer Aw, 1966)}

Discs diffusion method was used for antibiotic susceptibility of the isolates. This test was performed on Mueller Hinton agar plates. Suspension of the isolates was prepared using sterile distilled water and adjusted to $0.5 \mathrm{McF}$ arland standards. A $100 \mu 1$ suspension of freshly grown bacterial cultures was spread on Mueller Hinton agar plates. The antibiotic discs were placed on the surface of agar and the plates were incubated at $37^{\circ} \mathrm{C}$ for $24-48 \mathrm{hrs}$.

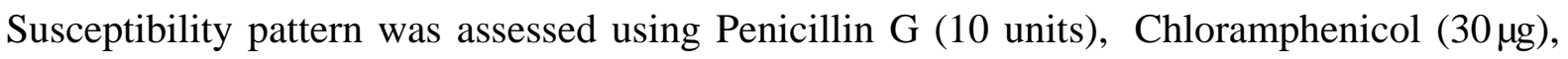
Erythromycin $(15 \mu \mathrm{g})$, Nitrofuran $(30 \mu \mathrm{g})$, Cephalosporin $(30 \mu \mathrm{g})$, Streptomycin $(10 \mu \mathrm{g})$ and Rifampicin $(5 \mu \mathrm{g})$.

\subsection{Probiotic efficacy test (Vijayan, K. K., 2006)}

In performing the probiotic efficacy test by well diffusion method (Magaldi S., 2004), nutrient agar plates were heavily seeded uniformly with the selected isolates. Then hole was made in media by sterile cork borer in aseptic condition. Then one drop of malted agar was poured into hole and allowed to solidify to make a base layer. After that specific amount $(0.1$ $\mathrm{ml}$ ) culture filtrate of probiotic bacteria (Bacillus sp. \& Pediococcus sp.) was poured into two separate holes. For maximum diffusion, the culture plates were kept at low temperature $\left(4^{\circ} \mathrm{C}\right)$ for 2-4 hours. The plates were then incubated at $37^{\circ} \mathrm{C}$ for 24 hours to allow maximum growth of the organisms at inverted position. The efficacy of the probiotic was determined by measuring the zone of inhibition expressed in millimeter in diameter. The experiment was carried out more than once and mean of reading was taken.

\section{Result and Discussion:}

\subsection{Determination of Total Bacterial Count And Vibrio Load Count of the Collected Samples}

The total bacterial count and Vibrio load count of collected samples are shown in the Table 1. There is a variation in the bacterial count and Vibrio load count among different types of samples. (Figure 1) 


\section{Macrothink}

Journal of Biology and Life Science

ISSN 2157-6076

2018, Vol. 9, No. 1

Table 1: Total bacterial count and Vibrio load count of the collected samples at investigated sites

\begin{tabular}{|c|c|c|c|c|}
\hline $\begin{array}{l}\text { Sl. } \\
\text { No. }\end{array}$ & Location & Type of Sample & $\begin{array}{l}\text { Total Bacterial } \\
\text { Count (cfu/ml) }\end{array}$ & $\begin{array}{c}\text { Vibrio Load } \\
\text { Count (cfu/ml) }\end{array}$ \\
\hline \multirow{2}{*}{1.} & \multirow{2}{*}{ Dumping water zone at Kolatali, Cox'bazar } & Water sample & $7.06 \times 10^{5}$ & $4.58 \times 10^{5}$ \\
\hline & & Soil sample & $7.27 \times 10^{6}$ & $4.6 \times 10^{6}$ \\
\hline \multirow{2}{*}{2.} & \multirow{2}{*}{ Mixing water zone at Kolatali, Cox'bazar } & Water sample & $1.15 \times 10^{3}$ & $5.07 \times 10^{2}$ \\
\hline & & Soil sample & $5.04 \times 10^{3}$ & $2.74 \times 10^{3}$ \\
\hline \multirow{3}{*}{3.} & \multirow{3}{*}{ Diamond Hatchery, Cox'sbazar } & Raw water & $3.22 \times 10^{2}$ & $1.6 \times 10^{2}$ \\
\hline & & Treated water & $4.49 \times 10^{1}$ & $3.21 \times 10^{1}$ \\
\hline & & Water from algal culture & $2.94 \times 10^{3}$ & $1.52 \times 10^{3}$ \\
\hline \multirow{2}{*}{4.} & \multirow{2}{*}{ Beximco Fisheries, Cox'sbazar } & Raw water & $2.14 \times 10^{3}$ & $1.03 \times 10^{3}$ \\
\hline & & Treated water & $5.31 \times 10^{2}$ & $2.76 \times 10^{2}$ \\
\hline \multirow{2}{*}{5.} & \multirow{2}{*}{ Dumping water zone at Sonapara, Cox'bazar } & Water sample & $1.56 \times 10^{6}$ & $9.82 \times 10^{5}$ \\
\hline & & Soil sample & $1.18 \times 10^{7}$ & $6.84 \times 10^{6}$ \\
\hline \multirow{2}{*}{6.} & \multirow{2}{*}{ Mixing water zone at Sonapara, Cox'bazar } & Water sample & $6.54 \times 10^{3}$ & $3.99 \times 10^{3}$ \\
\hline & & Soil sample & $1.17 \times 10^{4}$ & $6.55 \times 10^{4}$ \\
\hline \multirow{3}{*}{7.} & \multirow{3}{*}{ Grameen Hatchery, Cox'sbazar } & Raw water & $3.37 \times 10^{2}$ & $1.65 \times 10^{2}$ \\
\hline & & Treated water & $5.6 \times 10^{1}$ & $3.62 \times 10^{1}$ \\
\hline & & Water from algal culture & $3.09 \times 10^{3}$ & $1.61 \times 10^{3}$ \\
\hline \multirow{3}{*}{8.} & \multirow{3}{*}{ Quality Hatchery, Cox’sbazar } & Raw water & $2.98 \times 10^{2}$ & $1.44 \times 10^{2}$ \\
\hline & & Treated water & $3.05 \times 10^{1}$ & 0 \\
\hline & & Water from post larval culture & $1.03 \times 10^{2}$ & $4.39 \times 10^{1}$ \\
\hline
\end{tabular}

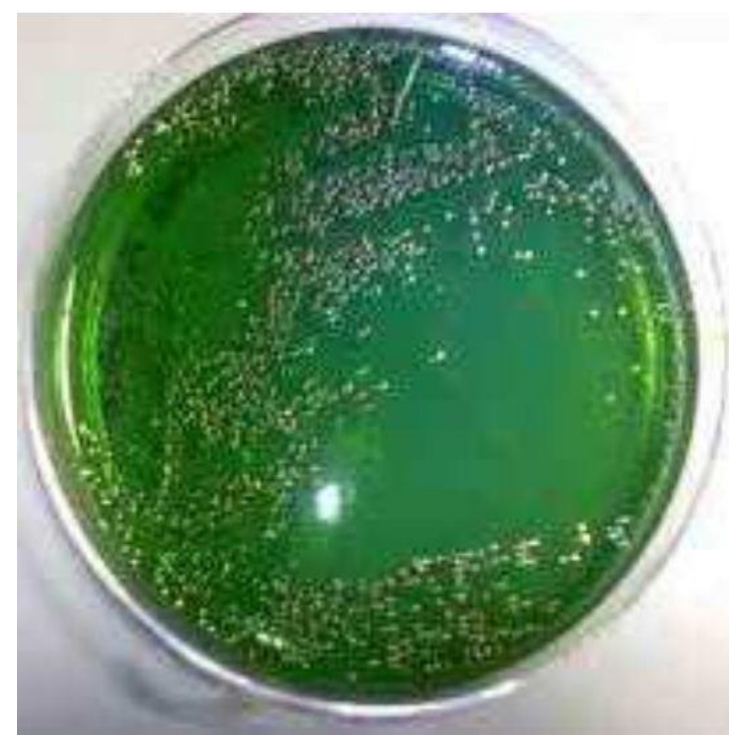

Figure 1: Vibrio Load Count on TCBS Agar Medium 


\section{Macrothink

The maximum bacterial load was found to exist in the soil sample of dumping ground and the total bacterial load at the zone of mixing point of hatchery discharged water with sea water was next to it. The waste water of hatchery discharged with poor or no treatment is supposed to be responsible for making the raw sea water contaminated. Wang and his co-workers (2005b) published their studies on total bacterial count of new and 3 years old grow out pond which was under cultivation of Liptopenaeus vannamei. Their finding revealed that total bacterial count of recently constructed pond was $1.11 \times 10^{6} \mathrm{cfu} / \mathrm{ml}$, while it was $6.25 \times 10^{6}$ cfu/ml for 3 years old pound. According to Sung et al. (2001) (Ohhira, I.,1996). In the present study, the bacterial count in hatchery system was found to be less than what was demonstrated in earlier studies. Though the number bacteria represent a lower value comparing with the previous research, the possibility of presence of pathogenic microorganisms in the shrimp culture system is not out of consideration.

\subsection{Isolation and Selection of the Bacteria from the Samples}

During the period of study, a total number of 20 bacterial colonies were isolated according to morphological characteristics. Among them 7 groups of isolates were screened for further study on the basis of their morphological and cultural characteristics. The selected isolates were designated as AM1, AM2, AM3, AM4, AM5, AM6 and AM7.

\subsection{Characterization and Identification of the Selected Isolates}

Seven isolates were finally selected from seven groups for detail study. The purpose of characterization and identification was to place the microorganisms into a specific class or group so that the characteristics of these unknown organisms can be compared with others. The bacterial isolates were characterized on the basis of their morphological characteristics including size and shape of the organism, arrangement of the cells, presence or absence of the spores, regular or irregular forms, gram reaction etc.; cultural and physiological characteristics including temperature tolerance, salt tolerance, IMViC test, $\mathrm{H}_{2} \mathrm{~S}$ production, nitrate reduction, deep glucose agar test, fermentation of different carbohydrates etc. All these characteristics were then compared with the standard description of "Bergey's Manual of Determinative Bacteriology", 8th ed. (Buchanon RE.,1974). Out of seven isolates, three were found to belong to the genus Vibrio, two were Aeromonas, one belongs to the genus Bacillus and the other was found to be Escherichia. The detail of the results can be seen in Table 2 . 
Table 2: Morphological and biochemical test result of selected isolates.

\begin{tabular}{|c|c|c|c|c|c|c|c|}
\hline Parameters & AM! & AM2 & AM3 & AM4 & AM5 & AM6 & AM7 \\
\hline Vegetative cells & $\begin{array}{l}\text { Short rod } \\
(0.3-1.0 \mu \mathrm{m}\end{array}$ & $\begin{array}{l}\text { Curved rod } \\
(0.5-0.8 \mu \mathrm{m}\end{array}$ & $\begin{array}{l}\text { Short rod } \\
(1.75-2.63 \\
\mu \mathrm{m}\end{array}$ & $\begin{array}{l}\text { Curved rod } \\
(0.5-0.8 \mu \mathrm{m}\end{array}$ & $\begin{array}{l}\text { Straight rod } \\
(1.1-1.5 \mu \mathrm{m}\end{array}$ & $\begin{array}{l}\text { Curved rod } \\
(1.1-1.5 \mu \mathrm{m}\end{array}$ & $\begin{array}{l}\text { Straight rod } \\
(0.5-0.8 \mu \mathrm{m}\end{array}$ \\
\hline Cell arrangement & $\begin{array}{l}\text { Single or in } \\
\text { pair }\end{array}$ & Single & $\begin{array}{l}\text { Single, } \\
\text { pair, short } \\
\text { chain. }\end{array}$ & Single & $\begin{array}{l}\text { Single or in } \\
\text { pair }\end{array}$ & Single & $\begin{array}{l}\text { Single or in } \\
\text { pai }\end{array}$ \\
\hline Gram staining & Gram -ve & Gram -ve & Gram +Ve & Gram -ve & Gram -ve & Gram -ve & Gram -ve \\
\hline Spore staining & $\begin{array}{l}\text { Non-spore } \\
\text { former }\end{array}$ & $\begin{array}{l}\text { Non-spore } \\
\text { former }\end{array}$ & $\begin{array}{l}\text { Spore } \\
\text { former }\end{array}$ & $\begin{array}{l}\text { Non-spore } \\
\text { former }\end{array}$ & $\begin{array}{l}\text { Non-spore } \\
\text { former }\end{array}$ & $\begin{array}{l}\text { Non-spore } \\
\text { former }\end{array}$ & $\begin{array}{l}\text { Non-spore } \\
\text { former }\end{array}$ \\
\hline Motility test & Motile & Motile & Non motile & Motile & Motile & Motile & Motile \\
\hline Catalase test & + & + & + & + & + & - & - \\
\hline Glucose broth & $\begin{array}{l}\text { Turbid } \\
\text { growth }\end{array}$ & $\begin{array}{l}\text { Turbid } \\
\text { growth }\end{array}$ & $\begin{array}{l}\text { Turbid } \\
\text { growth }\end{array}$ & $\begin{array}{l}\text { Turbid } \\
\text { growth }\end{array}$ & $\begin{array}{l}\text { Turbid } \\
\text { growth }\end{array}$ & $\begin{array}{l}\text { Turbid } \\
\text { growth }\end{array}$ & $\begin{array}{l}\text { Turbid } \\
\text { growth }\end{array}$ \\
\hline $\begin{array}{l}\text { Deep glucose } \\
\text { agar test }\end{array}$ & $\begin{array}{l}\text { Facultative } \\
\text { Anaerobic }\end{array}$ & $\begin{array}{l}\text { Facultative } \\
\text { Anaerobic }\end{array}$ & Aerobic & $\begin{array}{l}\text { Facultative } \\
\text { Anaerobic }\end{array}$ & $\begin{array}{l}\text { Facultative } \\
\text { Anaerobic }\end{array}$ & $\begin{array}{l}\text { Facultative } \\
\text { Anaerobic }\end{array}$ & $\begin{array}{l}\text { Facultative } \\
\text { Anaerobic }\end{array}$ \\
\hline Casein hydrolysis & - & + & - & + & + & + & - \\
\hline Starch hydrolysis & - & + & + & + & + & + & - \\
\hline Egg albumin test & - & - & + & - & + & + & - \\
\hline $\begin{array}{l}\text { Gelatin } \\
\text { liquefaction }\end{array}$ & + & + & - & + & - & + & + \\
\hline $\begin{array}{l}\text { Growth in } \\
\text { synthetic media }\end{array}$ & - & - & - & - & - & - & - \\
\hline $\begin{array}{l}\text { Growth in } \\
\text { inorganic salt }\end{array}$ & + & + & - & + & - & + & + \\
\hline Citrate utilization & - & + & - & + & - & + & Variable \\
\hline $\begin{array}{l}\text { Voges-Proskauer } \\
\text { test }\end{array}$ & - & - & - & - & - & - & Variable \\
\hline Methyl red test & + & + & - & + & + & + & + \\
\hline $\begin{array}{l}\text { Nitrate reduction } \\
\text { test }\end{array}$ & + & + & + & + & + & + & + \\
\hline $\mathrm{H} 2 \mathrm{~S}$ production & - & - & + & - & - & - & - \\
\hline Indole test & - & Variable & - & + & + & + & + \\
\hline Urease test & - & - & + & - & - & + & - \\
\hline Oxidase test & + & + & - & + & - & + & + \\
\hline glucose, & $\begin{array}{l}\text { Acid and } \\
\text { gas }\end{array}$ & $\begin{array}{l}\text { Acid and } \\
\text { gas }\end{array}$ & $\begin{array}{l}\text { No acid } \\
\text { and gas }\end{array}$ & $\begin{array}{l}\text { Acid } \\
\text { without gas }\end{array}$ & Acid from & $\begin{array}{l}\text { Acid but no } \\
\text { gas }\end{array}$ & $\begin{array}{l}\text { Acid and } \\
\text { gas }\end{array}$ \\
\hline
\end{tabular}




\begin{tabular}{|c|c|c|c|c|c|c|c|}
\hline galactose & $\begin{array}{l}\text { Acid and } \\
\text { gas }\end{array}$ & + & $\begin{array}{l}\text { Alkali } \\
\text { without gas }\end{array}$ & $\begin{array}{l}\text { Alkali } \\
\text { without gas }\end{array}$ & Acid from & Acid and gas & Acid and gas \\
\hline sucrose & $\begin{array}{l}\text { Alkali } \\
\text { without gas }\end{array}$ & - & $\begin{array}{l}\text { No acid and } \\
\text { gas }\end{array}$ & $\begin{array}{l}\text { Acid and } \\
\text { gas }\end{array}$ & $\begin{array}{l}\text { Alkali } \\
\text { without gas }\end{array}$ & Acid and gas & $\begin{array}{l}\text { Acid but no } \\
\text { gas }\end{array}$ \\
\hline lactose & $\begin{array}{l}\text { Alkali } \\
\text { without gas }\end{array}$ & - & $\begin{array}{l}\text { Alkali } \\
\text { without gas }\end{array}$ & $\begin{array}{l}\text { Acid } \\
\text { without gas }\end{array}$ & Acid from & $\begin{array}{l}\text { Alkali } \\
\text { without gas }\end{array}$ & Acid and gas \\
\hline xylose, & $\begin{array}{l}\text { Alkali } \\
\text { without gas }\end{array}$ & - & $\begin{array}{l}\text { No acid and } \\
\text { gas }\end{array}$ & $\begin{array}{l}\text { Alkali } \\
\text { without gas }\end{array}$ & $\begin{array}{l}\text { Alkali } \\
\text { without gas }\end{array}$ & $\begin{array}{l}\text { Alkali } \\
\text { without gas }\end{array}$ & $\begin{array}{l}\text { Alkali } \\
\text { without gas }\end{array}$ \\
\hline arabinose & $\begin{array}{l}\text { Alkali } \\
\text { without gas }\end{array}$ & + & $\begin{array}{l}\text { No acid and } \\
\text { gas }\end{array}$ & $\begin{array}{l}\text { Acid and } \\
\text { gas }\end{array}$ & Acid from & $\begin{array}{l}\text { Alkali } \\
\text { without gas }\end{array}$ & $\begin{array}{l}\text { Acid but no } \\
\text { gas }\end{array}$ \\
\hline maltose & $\begin{array}{l}\text { Alkali } \\
\text { without gas }\end{array}$ & + & $\begin{array}{l}\text { No acid and } \\
\text { gas }\end{array}$ & $\begin{array}{l}\text { Acid } \\
\text { without gas }\end{array}$ & $\begin{array}{l}\text { Alkali } \\
\text { without gas }\end{array}$ & $\begin{array}{l}\text { Acid but no } \\
\text { gas }\end{array}$ & $\begin{array}{l}\text { Acid but no } \\
\text { gas }\end{array}$ \\
\hline mannitol & $\begin{array}{l}\text { Alkali } \\
\text { without gas }\end{array}$ & + & $\begin{array}{l}\text { Alkali } \\
\text { without gas }\end{array}$ & $\begin{array}{l}\text { Acid } \\
\text { without gas }\end{array}$ & Acid from & Acid and gas & $\begin{array}{l}\text { Acid but no } \\
\text { gas }\end{array}$ \\
\hline $\mathrm{pH} 4.5$ & ++++ & ++ & - & - & +++ & + & + \\
\hline pH 6.5 & ++++ & +++ & ++++ & +++ & +++ & ++ & ++ \\
\hline $\mathrm{pH} 7.5$ & +++ & +++ & +++ & +++ & +++ & +++ & +++ \\
\hline pH 8.5 & +++ & ++ & - & - & ++ & ++ & +++ \\
\hline $\begin{array}{l}\text { Temperature } \\
\left(5{ }^{0} \mathrm{C}\right)\end{array}$ & - & - & + & + & - & - & - \\
\hline $\begin{array}{l}\text { Temperature } \\
\left(10{ }^{0} \mathrm{C}\right)\end{array}$ & - & + & + & + & - & - & - \\
\hline $\begin{array}{l}\text { Temperature } \\
\left(27^{0} \mathrm{C}\right)\end{array}$ & +++ & +++ & +++ & +++ & +++ & +++ & +++ \\
\hline $\begin{array}{l}\text { Temperature } \\
\left(37^{0} \mathrm{C}\right)\end{array}$ & +++ & +++ & +++ & +++ & +++ & +++ & +++ \\
\hline $\begin{array}{l}\text { Temperature } \\
\left(45^{0} \mathrm{C}\right)\end{array}$ & - & - & - & - & - & - & - \\
\hline
\end{tabular}

The above characteristics of selected isolate were compared with the standard description given in 'Bergey's Manual of Determinative Bacteriology', 8th ed. .(Buchanon RE.,1974) and found closely related to the below species

Code of Isolates

AM1
Name of Species

Aeromonas salmonicida

Vibrio parahaemolyticus

Bacillus fastidiosus 


$\begin{array}{ll}\text { AM4 } & \text { Vibrio vulnificus } \\ \text { AM5 } & \text { E. coli } \\ \text { AM6 } & \text { Vibrio harveyi } \\ \text { AM7 } & \text { Aeromonas bestiarum }\end{array}$

During the present work, identified Vibrio species were V. vulnificus, V. harveyi and $V$. parahaemolyticus which are commonly termed as the pathogenic bacteria for shrimp larvae. The Vibrio species identified in the present study are considered pathogenic for shrimp larvae. The other bacteria identified have also detrimental effect in shrimp hatchery management. The root cause of these bacterial infections was the improper treatment of raw water and storage condition of the storage tank was not sufficient enough to maintain it contamination free. Moreover, in hatcheries the algal culture tank was another vital source of potential bacterial contamination where both the total bacterial count and Vibrio load count were higher than other sources. It is evident $V$. harveyi is the most dominant pathogenic Vibrio species that has got a greater effect on shrimp PL during the rearing period. Similarly in our present study, the Vibrio load count accounts for almost $40 \%$ of the total bacterial count. Besides, out of seven isolates identified, Vibrio remains dominant representing three different pathogenic species. According to Lavilla-Pitogo et al, 1998, Australia; (Lavilla-Pitago, C. R.,1998) and Karunasagar et al, 1994; (Karunasagar, I.,1994), Luminous bacteria particularly $V$. harveyi and occasionally other luminous species have become recognized as a devastating pathogen of Penaeid shrimp larvae and adults throughout South -east Asia. The salinity of this area is facilitation for pathogenic Vibrio growth. This environment proved congenial for harmful LB species like Vibrio harveyi, V. fisheri, V. splendidus and V. vulnificus for their survival and multiplication. In preventing disease outburst in shrimp hatcheries especially the temperature of rearing water tanks need to be maintained at optimum levels, least fluctuations in temperature would lead to luminous vibriosis. Although motile aeromonads appropriately receive much notoriety as pathogens of fish. It is important to note that these bacteria also compose part of the normal intestinal microflora of healthy fish. Therefore, the presence of these bacteria, by itself, is not indicative of disease and, consequently, stress is often considered to be a contributing factor in outbreaks of disease caused by these bacteria.. In the present study, the bacterial genus Aeromonas was identified as the second most dominant bacteria in shrimp culture system. The prevalence of this bacterium is an indication of its relation in pathogenic infection of cultured shrimp. Two of the other bacteria identified; Bacillus fastidiosus and E. coli also reported to be present in the shrimp culture system of which Bacillus is used as the probiotic treatment in shrimp hatcheries to control other bacterial growth. Although E. coli is not so much reported in shrimp culture system, the presence of $E$. coli is not unexpected due to the widespread availability of this organism which is also regarded as the pathogenic microbes affecting the shrimp growth. 


\subsection{Antibiotic Susceptibility of the Selected Isolates}

The antibiotic susceptibility of the selected isolates was performed by disc diffusion method using the standard discs. The results of antibiotic susceptibility are shown the Figure 2. Among the antibiotic discs used Rifampicin showed inhibitory effect against almost all organisms where as ampicillin is the antibiotic which had no effect on either of the isolates and penicillin is less effective than other antibiotic used.

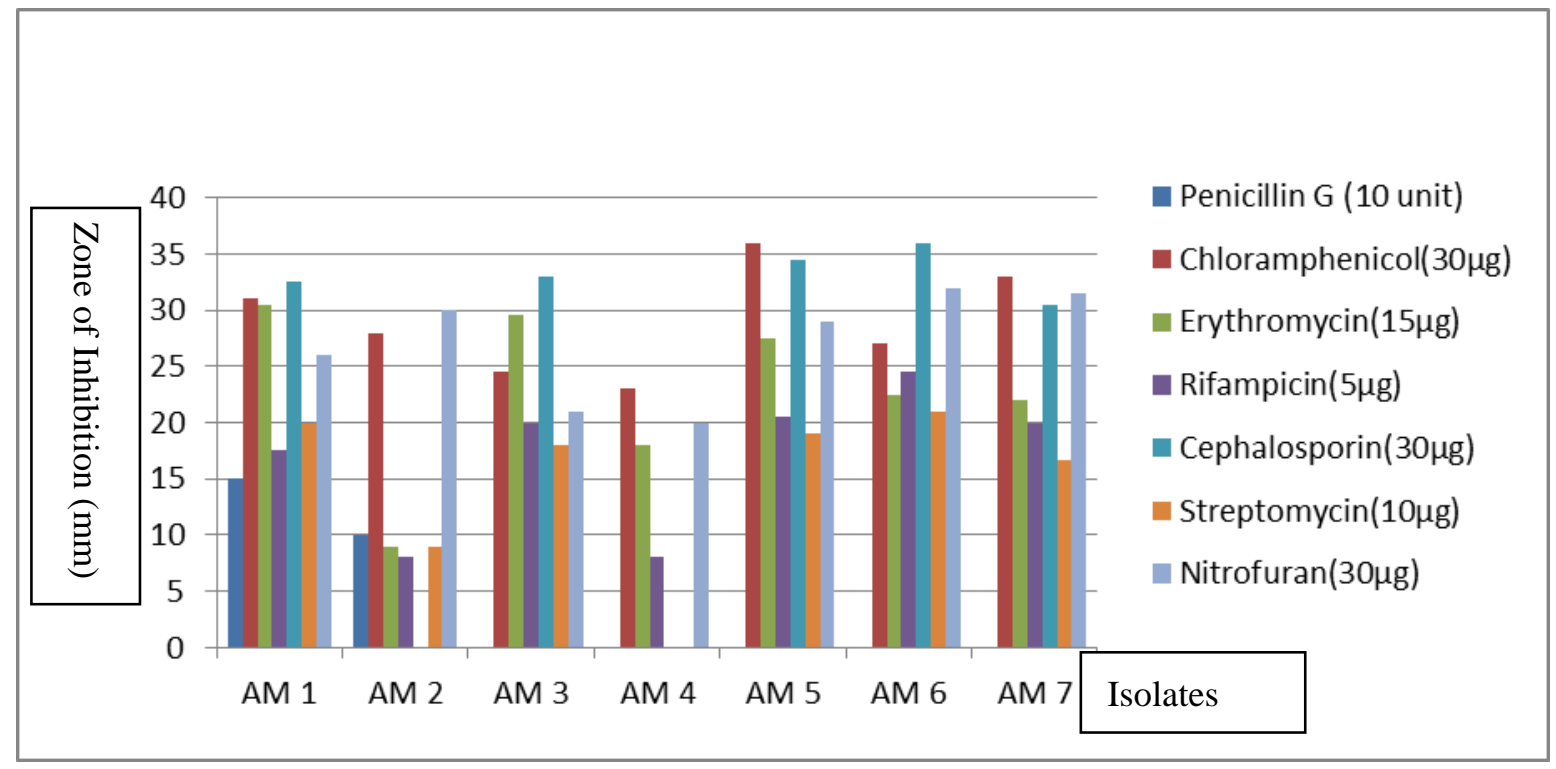

Figure 2: Antibiotic Susceptibility Test of the Selected Isolates.

All penaeid shrimp hatcheries encounter bacterial problems that impact on production. Antibiotic treatments to control pathogenic bacteria problems yields varying results. However, some of the antibiotics show effective results in controlling bacterial growth in aquaculture. Tjahjadi et al. (1994) reported that almost all of the bacteria that were isolated from seawater and hatchery-rearing water at Kalianget, East Java, including V. harveyi, were resistant to various antibiotics except rifampicin. Rifampicin, a bactericidal antibiotic, is active against gram-positive and some gram-negative bacteria. This drug interferes with transcription processes in bacteria and thus far was never used in shrimp hatchery. In the present study, a number of antibiotics were treated against the pathogenic microorganisms identified. Chloramphenicol, Erythromycin, Nitrofuran and Rifampicin are the four antibiotics that showed satisfactory inhibitory effect against all of the pathogenic microorganisms. The treatment of these antibiotics may have growth inhibitory effect upon the shrimp which requires further study.

However, with the use of antibiotics or disinfectants to kill bacteria, some bacteria survive (either strains of the pathogen or others) because they carry genes for resistance (Moriarty, D. J.,1998). These will then grow rapidly because their competitors are removed. Over a short period of time, antibiotic resistant bacterial strains develop and flourish. There is a risk of developing antibiotic resistance in these benign or beneficial bacteria, as bacteria have the capacity to transfer genetic information between themselves. A potential human or aquaculture species pathogen could acquire the genetic information required for antibiotic 
resistance from the much more numerous members of the normal bacterial community. So, whether the antibiotic has high or low activity, the use of it is concerned with the shrimp growth as well as human health.

\subsection{Probiotic Efficacy of Bacillus \& Pediococcus on the Selected Isolates}

The results of probiotic efficacy test are listed in the Figure 3. The results outlined that the probiotic organisms Bacillus \& Pediococcus have highest inhibitory effect on the isolate AM1 and the isolate AM5 was less affected by it. Almost all of the isolates were sensitive to the probiotic application leaving growth inhibitory effect. Probiotics, mostly Bacillus strain were used and assumed that the strain produced an antibiotic that inhibit the Vibrio growth, then the mortality rate of Vibrio increased, allowing the dominance of Bacillus, even if the antibiotic were not produced at high concentration to kill all Vibrio cells directly Bacillus and Pediococcus showed a satisfactory antimicrobial effect against the selected isolates which is favourable for the biocontrol of microbial flora in shrimp hatchery and aquaculture. The probiotic bacteria Bacillus and Pediococcus have the ability to induce the antipathogenic activity by producing antimicrobial metabolites when cultured with the pathogenic microorganisms.

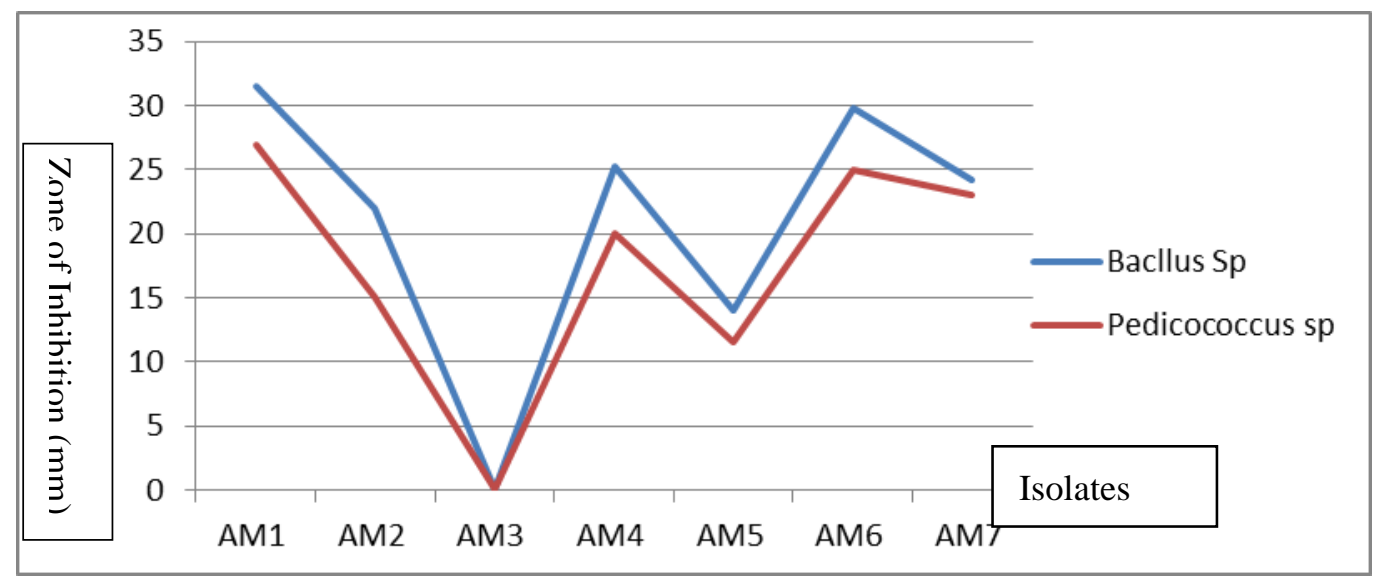

Figure 3: Probiotic efficacy test of Bacillus \& Pediococcus on the selected isolates

Bacillus and Pediococcus showed a satisfactory antimicrobial effect against the selected isolates which is favourable for the biocontrol of microbial flora in shrimp hatchery and aquaculture. The probiotic bacteria Bacillus and Pediococcus have the ability to induce the antipathogenic activity by producing antimicrobial metabolites when cultured with the pathogenic microorganisms. In the present study, the treatment of the identified pathogens with the crude extract of Bacillus and Pediococcus produce clear zone of inhibition surrounding the area of the crude extract applied. Here, no effect was found against the isolate AM3 (Bacillus fastidiosus) because the isolate itself a genus of the applied probiotic bacteria. So, the presence of probiotic bacteria within the shrimp aquaculture can cause the decrease of pathogenic microorganisms by its antimicrobial action. There are many reports on the anti-Vibrio activity of Bacillus spp. Production of bacteriocin or bacteriocin-like substances have been reported from Bacillus subtilis (Jansen, E.F., 1944), Baciluus thuringiensis (De Borjac H., 1974), , B. licheniformis (Bradley DE. 1967), and Use of 
Bacillus spp. probiotic has been reported in piglets (Ozawa, K., 1981) and in black tiger shrimp, Penaeus monodon [15]. The latter study showed that P. monodon larvae fed with Bacillus S11 showed $100 \%$ survival after challenge with pathogenic $V$. harveyi, while only $26 \%$ control animals survived. The use of Bacillus and Pediococcus as a probiotic in killing the pathogenic microorganisms present in shrimp culture and Hatchery production system is effective enough to facilitate the culture condition for shrimp larvae rearing; whereas the use of antibiotic as an antimicrobial agent may cause the growth inhibition of shrimp larvae itself. The preference for the use of Bacillus and Pediococcus as probiotic in shrimp hatchery and aquaculture is also more economical than the use of antibiotic.

\section{Conclusion}

Waste water discharged from shrimp hatchery and aquaculture without any or proper treatment is a potential source of microbial contamination within the shrimp culture. The untreated waste water gets mixed with sea water which is further used for hatchery operation. The representative microbial population within shrimp culture are the Vibrio spp., Aeromonas spp., Bacillus fastidiosus and E. coli among which Vibrio and Aeromonas are the pathogenic microorganisms causing disease of shrimp. The antibiotic effect upon the shrimp pathogen is strong enough to prevent microbial growth but at the same time antibiotic itself can cause inhibitory effect on shrimp growth. Alternatively, the use of probiotic bacteria to kill other bacteria is of great interest in preventing microbial contamination in shrimp culture. Finally, proper treatment of raw water before use, maintenance of personnel hygiene, treatment of waste water before discharge, use of appropriate dosage of antibiotic and probiotic treatment instead of antibiotic-are the requisites for a disease free shrimp culture system.

\section{Reference}

Alderman, D. J., \& Hastings, T. S. (1998). Antibiotic use in aquaculture: development of antibiotic resistance - potential for consumer health risks. International Journal of Food Science \& Technology. 33(2): 139-155. https//doi.org/10.1046/j.1365-2621.1998.3320139.x

American Public Health Association (APHA), (2002). Standard method for examination of water and wastewater.

Bauer Aw, Kirby Mm, Sherris Jc, \& Turuck M. (1966) Antibiotic susceptibility testing by a standardized single disc method. Am. J. Clin. Pathol. 45(4):493-496

Bradley, D. E. (1967). Ultrastructure of bacteriophage and bacteriocins. Bacteriol Rev. Dec; 31(4):230-314.

Buchanon, R. E., \& Gibson, N. E. (1974). Bergey's Manual of Determinative Bacteriology, 8th ed. Williams and Wilkins Co. Baltimore. Page: 530-534.

De Borjac, H., Lajudie, J. (1974). Mise en évidence de facteurs antagonistes du type des bactériocines chez Bacillus thuriengensis. Ann. Microbiol. (Paris) Ser. B 125:529-537.

Holt, J. G., Krieg, N. R., Sneath, Pha., Staley, J. T., \& Williams, S. T. (2000). Bergey’s manual of determinative bacteriology, 9th ed. Lippincott Williams and Wilkins, Baltimore. 
Pp-532,549-551,559,576,592.

Ivanovics, G. Bacteriocins and Bacteriocin-Like Substances. Bacteriol Rev. (1962). Jun;26(2 Pt 1):108-118.

J F Novotny, Jr, \& J J Perry. Characterization of bacteriocins from two strains of Bacillus thermoleovorans, a thermophilic hydrocarbon-utilizing species. Applied and Environmental Microbiology. 58(8).

Jansen, E. F., \& Hirschmann, D. J. (1944) Subtilin, an antibacterial product of Bacillus subtilis: culturing conditions and properties. Arch Biochem 4: 297-304.

https//doi/org/10.1046/j.1365-2958.2002.02869.x

Karunasagar, I., Pai, R., Malathi, G. R., \& Karunasagar, I. (1994). Mass mortalities of Penaeus monodon larvae due to antibiotic resistant Vibrio harveyi infection. Aquaculture, 128: 203-209. https://doi.org/10.1016/0044-8486(94)90309-3

Lavilla-Pitago, C. R., Leano, E. M. \& Paner, M. G. (1998). Mortalities of pond-cultured juvenile shrimp, Penaeus monodon, associated with dominance of luminescent Virbio, in the rearing environment. Aquaculture 164:337-349.

https://doi.org/10.1016/S0044-8486(98)00198-7

Lin, C.K. (1995). Progression of intensive shrimp culture in Thailand. P. 13-23. In Browdy, C.L. \& Hopkins, J.S. (eds.). Swimming Through Troubled Water, Proceedings of the Special Session on Shrimp Farming, Aquaculture'95. World Aquaculture Society, Baton Rouge

Magaldi, S., Mata-Essayag, S., Hartung, De Capriles C, Perez, C, Colella Mt, Olaizola C, Ontiveros, Y. (2004). Well diffusion for antifungal susceptibility testing. Int J Infect Dis.Volume 8, Issue 1, Pages 39-45. https://doi.org/10.1016/j.ijid.2003.03.002

Moriarty, D. J. W. (1998). Control of luminous Vibrio species in penaeid aquaculture ponds.Aquaculture 164:351-358. https://doi.org/10.1016/S0044-8486(98)00199-9

Ohhira, I., T. Tamura, N. Fujii, K. Inagaki, \& H. Tanaka. (1996). Antimicrobial activity against methicillin-resistant $\mathrm{Sk} /$ phyhcoccus aureus in the culture broth of Enterococcus faecalis TH10, an isolate from Malaysian fermentation food. Temph. Japanese J. Dairy and Food Sci., 45:93-96.

Otta, Karunasagar. Bacteriological study of shrimp, Penaeus monodonFabricius, hatcheries in India. Journal of Applied Ichthyology. Volume 17, Issue 2 .April 2001 Pages 59- 63.

Ozawa, K., Yokota, H., Kimura, M., \& Mitsuoka, T. (1981) Effects of administration of Bacillus subtilis strain BN on intestinal flora of weaning piglets. Nippon Juigaku Zasshi 43, 771-775. https://doi.org/10.1292/jvms1939.43.771

Sanders, E. R. Aseptic Laboratory Techniques: Plating Methods. J. Vis. Exp. (63), e3064, https//doi.org/10.3791/3064

Shakibazadeh, S., Roos, S. C., Hafezieh, M., Christianus, A., Kamarudin, M. S., \& Kamaruzaman, S. (2012). A putative probiotic isolated from hatchery reared juvenile Penaeus 


\section{Macrothink}

monodon. Iranian Journal of Fisheries Sciences. 11(4): 849-866.

Subasinghe, R. (1997). Fish Health and Quarantine. In Review of the State of World Aquaculture, FAO Fisheries Circular no. 886. FAO of United Nations, Rome., 45-49

Sung, H. H., Hsu, S. F. Chen, C. K., Ting, Y. Y. Chao, W. L. (2001). Relationships between disease outbreak in cultured tiger shrimp (Penaeus monodon) and the composition of Vibriocommunities in pond water and shrimp hepatopancreas during cultivation Aquaculture, 192, 101-110. https://doi.org/10.1016/S0044-8486(00)00458-0

Tjahjadi, M. R., Angka, S. L., \& Suwanto, A. (1994). Isolation and evaluation of marine bacteria for biocontrol of luminous bacterial disease in tiger shrimp larvae (Penaeus monodon, Fab.). Asia Pac J Mol Biol Biotechnol 2, 347-352. https//doi.org/10.1007/s11274-009-9992-7

Vijayan, K. K., Singh, I. S. B., Jayaprakash, N. S., Alavandi, S. V., Pai, S. S., Preetha, R., Rajan, J. J. S. \& Santiago, T. C. (2006). A brackishwater isolate of Pseudomonas PS-102, a potential antagonistic bacterium against pathogenic vibrios in penaeid and nonpenaeid rearing systems. Aquaculture 251: 192-200. https://doi.org/10.1016/j.aquaculture.2005.10.010

World Health Organization Antimicrobial Resistance Fact Sheet 194, http://www.who.int/inf-fs/en/fact 194.html

Yasuda, K., \& Kitao, T. (1980). Bacterial flora in the digestive tract of prawns, Penaeus Japonicus bate. Aquaculture, 19, 229-234. https://doi.org/10.1016/0044-8486(80)90046-0

\section{Copyright Disclaimer}

Copyright for this article is retained by the author(s), with first publication rights granted to the journal.

This is an open-access article distributed under the terms and conditions of the Creative Commons Attribution license (http://creativecommons.org/licenses/by/3.0/). 